\title{
Review of Some Procedural Witness Protective Measures at the International Criminal Tribunal for the Former Yugoslavia
}

\author{
Romina Beqiri \\ Faculty of Law, European University of Tirana, Albania
}

Doi: 10.19044/esj.2017.v13n34p251 URL:http://dx.doi.org/10.19044/esj.2017.v13n34p251

\begin{abstract}
Given the spread terror and the abuses perpetrated in the Balkan region, many victims and witnesses of atrocities were deterred from testifying. The International Criminal Tribunal for the former Yugoslavia (ICTY or Tribunal) facilitated the appearance of witnesses and protected them in case of intimidation including by taking measures against those who would violate the confidentiality of the proceedings. This article aims to introduce some of the witness protective measures before the Tribunal, and particularly threats and risks they have faced in the context of the cases dealt with by the Tribunal. It reflects also upon groundbreaking measures of protection decided by the Tribunal and the challenges it has faced over the last two decades. It finally discusses the impact of such challenges on the right to a fair trial and how they were addressed.
\end{abstract}

Keywords: Witness protection, procedural measures, fair trial, contempt, intimidation

\section{Introduction}

The International Criminal Tribunal for the Former Yugoslavia (ICTY) is well recognized for its uniqueness as an ad hoc International Tribunal whose responsibility was to establish the truth and punish the perpetrators accounted for the war crimes and genocide during the armed conflict in the former Yugoslavia ${ }^{4}$. In the last two decades, the Tribunal has exercised its jurisdiction over war crimes, crimes against humanity and genocide and has enriched the jurisprudence of international criminal law. As noted in the "Echoes of Testimonies - A Pilot Study into the long-term impact of bearing witness before the ICTY (2016)":

${ }^{4}$ UN. Doc. S/RES/827, 25 May 1993. 
"The ICTY has shared its wealth of knowledge and experience with communities in the former Yugoslavia through judicial capacity building, outreach in the local communities, development of curricula and materials on international criminal and humanitarian law, legal and witness support, peer-to-peer training, and access to ICTY materials translated into local languages".

One of the unique considerations of ICTY Statute is the affirmative obligation to protect victims and witnesses interacting with the Tribunal. Following the jurisprudence of the ICTY, in Aleksovski case ${ }^{5}$, the protection measures are of primary importance; not only for the protection of the lives of the witnesses, but also for the functioning of the Tribunal (De Brouwer, 2015:714). The witnesses who testified before the ICTY were victims or survivors, well-placed (or "insider") witnesses (that is, persons who have held high office in the government, the army and the police), perpetrators of crimes (pleading guilty in whole or in part to the offences with which they are charged and agreeing to testify for the Prosecution), or expert witnesses (in special fields such as, for example, military doctrine or the law applicable in the former Yugoslavia) ${ }^{6}$.

Among the facts that the abuses perpetrated in the former Yugoslav or The Balkans region have spread terror and anguish among the civilian population, the ICTY Judges feared that many victims and witnesses of atrocities would be deterred from testifying for the crimes occurred or would be concerned about the potential negative consequences that their testimony could have for themselves or their families ${ }^{7}$. This was a challenging aspect and also troubling one for a new ad hoc criminal tribunal given that, unlike the Nuremberg tribunal where the Prosecutors had access to many documents relating to atrocities committed by the Nazis during the Second World War, the prosecutors of the ICTY (Bonnet, 2005) were mostly and considerably dependent on the testimony of eyewitnesses (Morris and Scharf, 1995:242) of atrocities committed in the territory of former Yugoslavia ${ }^{8}$.

\footnotetext{
${ }^{5}$ The Prosecutor v. Zlatko Aleksovski, "Décision Portant Condamnation Pour Outrage Au Tribunal", IT-95-14/1-T, 11 December 1998; cited in: ICTY Press Release, 'Mr. Nobilo Found to be in Contempt of the Tribunal', 15 December 1998.

${ }^{6}$ Jean-Charles Gardetto, Memorandum on "The protection of witnesses as a cornerstone for justice and reconciliation in the Balkans", Committee on Legal Affairs and Human Rights of the Council of Europe, AS/Jur (2009) 38, 3 September 2009, para. 20.

7 The Prosecutor v Duško Tadic, ICTY Case No.: IT-94-1, "Decision on the Prosecutor's Motion requesting Protective Measures for Victims and Witnesses", 10 August 1995, para. 23.

${ }^{8}$ Ibid.
} 
The applicable provisions related to witnesses are Articles 20, 21 and 22 of the ICTY Statute which are also referred to as the "fair trial provisions" (Ackerman and O'Sullivan, 2000:122) of the Statute, and Rules 53, 54, 69, 73 and 75 of the Rules of Procedure and Evidence which provide for the protection of witnesses testifying before the Tribunal. These provisions enumerate a number of protective measures ranging from expunging names and identifying information from Tribunal records through testimony under a pseudonym, electronic facial distortion, voice distortion and closed session; ${ }^{9}$ or testimony by way of video-link and testimony from a remote witness room which are available in the Rule 75 of the Rules of Procedure and Evidence.

The protective measures would be ordered for the purpose of public order or morality, safety, security or non-disclosure of the identity of a victim or witness as provided for in Rule 75; or the protection of the interests of justice.

Below, this article analyses, while taking into account the Defence right to a fair trial, some of the mostly used protective measures such as the protection from the public and media, anonymity and measures taken to address any breach of the confidentiality of the witness identity in the context of contempt cases.

\section{Protection Of Witnesses From The Public And The Media}

The responsibility of the Chamber is to ensure that the trial is fair and conducted in accordance with the Statute and the Rules. However in many aspects it established legal precedents "in uncharted waters". ${ }^{10}$ Given that the general principle of a fair trial is that hearings shall be public, a Trial Chamber, despite its preference ${ }^{11}$, may decide to deviate from the principle and to close the proceedings in accordance with its rules of procedure and evidence. $^{12}$

Generally the Prosecutor's requests have direct implications for the accused's right to a public hearing, although in many cases in ICTY, the Defence agreed to these requests for most witnesses. ${ }^{13}$ In the Tadic case, the Trial Chamber Judges were in favour of an open and public trial ${ }^{14}$ having considered that the International Tribunal has an educational function and the

\footnotetext{
${ }^{9}$ Rule 75(B)(ii): "Measures for the Protection of Victims and Witnesses".

${ }^{10}$ In Tadic, Decision of 10 August 1995, para. 31.

11 This preference for public hearings is evident in Article 20(4) of the Statute, which requires that: "The hearings shall be public unless the Trial Chamber decides to close the proceedings in accordance with its rules of procedure and evidence."

${ }_{12}$ Article 20(4) of the ICTY Statute.

${ }^{13}$ In Tadic, Decision of 10 August 1995, para. 31.

${ }^{14}$ Ibid., para 32.
} 
publication of its activities helps to achieve that goal. Furthermore, the limitation of public hearings is expressed in Rule 78 which provides that all proceedings before a Trial Chamber shall be held in public, unless exceptional reasons require keeping them confidential. This principle is also established in the United Nations Mechanism for the International Criminal Tribunals (MICT) ${ }^{15}$ Orić and Karadžić cases ${ }^{16}$. This limitation is nothing but the balance between fair trial and the rights of the accused to a public hearing on the one hand, and other mandated interests, such as the duty to protect victims and witnesses, on the other hand ${ }^{17}$. At Pre-trial stage, Rule 69 allows for the non-disclosure of the identity of a victim or a witness who may be in danger until the witness is brought under the protection of the Tribunal. This delay in the disclosure of the identity potentially affects the duration of the proceedings as the accused has to wait until the witness or victim is under the Court's protection to prepare the cross-examination.

This balance is expressly required in Rule 79, which provides that the press and public may be excluded from the proceedings for various reasons, including the safety or non-disclosure of the identity of a victim or witness. As such, in certain circumstances, the right of the accused to a public hearing will be restricted in consideration of the interest of protected witness. These qualifications on the right to a public hearing are permitted under the Statute and Rules ${ }^{18}$. Pursuant to Rule 79 , a Trial Chamber may hold in camera proceedings and the following measures to prevent disclosure to the public or the media of the identity of a victim or a witness, or of persons related to or associated with him by the following means:

(a) expunging names and identifying information from the Chamber's public records;

(b) non-disclosure to the public of any records identifying the victim;

(c) giving of testimony through image- or voice- altering devices or closed circuit television; and

${ }^{15}$ MICT was established by the United Nations Security Council in 2010. The MICT is charged with carrying out a number of essential functions of the ICTR and the ICTY after completion of their respective mandates. In July 2013, the Hague branch of the MICT started to handle all remaining issues of the Tribunal's mandate, including the completion of cases on appeal for which notice is filed after 1 July 2013, and preservation, security, and accessibility of thousands of linear meters of physical records and petabytes of digital records generated as a result of the Tribunals' work.

${ }^{16}$ The Prosecutor v. Radovan Karadžić, Case No. MICT-13-55-A, "Decision on a Motion to Compel Inspection of Pseudonyms of Witnesses Subject to Ex Parte Rule 86 Proceedings", 22 May 2017. Prosecutor v. Naser Orić, Case No. MICT-14-79, "Decision on an Application for Leave to Appeal the Single Judge's Decision of 10 December 2015", 17 February 2016, para. 8.

${ }^{17}$ Ibid., para 33.

${ }^{18}$ Ibid., para 34. 
(d) assignment of a pseudonym.

In the same vein, the Trial Chambers ordered Closed Sessions and took appropriate measures to facilitate the testimony of vulnerable victims and witnesses, such as one-way closed circuit television.

It is clear that these provisions highlight that the proceedings must be public unless good cause is shown to the contrary ${ }^{19}$. One major technological advantage in the ICTY's protection measure is that the broadcast is released after a delay of 30 minutes. This allows the parties to seek redaction of any inadvertent reference to a protected witness or to potentially identifying information (McLaughlin, 2007:197). Such a measure has become a feature in protecting witnesses or information before all international criminal tribunals.

In the Tadic case, the Judges ruled that measures to protect the confidentiality of victims and witnesses have to be consistent with other human rights jurisprudence (International Covenant on Civil and Political Rights (ICCPR) and European Convention of Human Rights (ECHR)) despite the opposition of the Defence that the protection of victims and witnesses is not sufficient to set aside the right of the accused to a fair and public hearing.

In determining where the balance lies between the right of the accused to a fair and public trial and the protection of victims and witnesses, consideration has been given to the special concerns of victims of sexual assault and their individual circumstances. In other words, their vulnerability is taken into account by the Chamber. These concerns have been factored into the balance on an individual basis for each witness for whom protection is sought ${ }^{20}$. The Judges deemed reasonable to admit that "these measures in no way affect the accused's right to a fair and public trial" 21 . The protective measures sought pursuant to Rule 75 will afford these witnesses privacy and guard against their re-traumatization should they choose to testify at trial. ${ }^{22}$ Some of the adequate in-court measures of protection that were provided to witnesses without resorting to closed circuit television was the removal of the witness from the courtroom and alternative methods such as the installation of temporary screens in the courtroom, positioned so that the witness cannot see the accused but the accused may view the witness via the courtroom monitors if full anonymity is not ordered by the Trial Chamber.

\footnotetext{
${ }^{19}$ Article 21(2) of the ICTY Statute.

${ }^{20}$ Witness $\mathrm{F}$ is an alleged victim of forcible sexual intercourse. Witnesses G, H and I are alleged victims of or witnesses to sexual mutilation. The measures sought by the Prosecutor are appropriate to protect the privacy rights of witnesses F, G, H and I. Decision of 10 August 1995, para. 50.

${ }^{21}$ Ibid., para. 50.

${ }^{22}$ Ibid.
} 
These screens gave the Chamber and the accused the benefit of observing directly the demeanour of the witness.

ICTY judgments justified confidentiality if special considerations exist; such as in cases involving sexual assault. In the context of the conflict in the former Yugoslavia, even in cases not concerning sexual assault, sufficient considerations to justify confidentiality were found in the fear of reprisals during an ongoing conflict, particularly given the mandated duty of the Tribunal to protect victims and witnesses and its inability to guarantee the safety of the victim or witness due to the lack of a fully-funded and operational witness protection programme ${ }^{23}$.

There is no doubt that the benefit of protection from public and media is a more acceptable measure from all the parties in the proceedings. This is because not only it keeps the victims and witnesses safe from the public, but it also allows the accused to know the identity of the witnesses testifying against him and to still be able to fully prepare to cross-examine these witnesses (McLaughlin, 2007:199).

\section{Anonymity As A Procedural Protective Measure and The Accused Right To A Fair Trial}

A key principle for establishing a fair and transparent trial is to give due importance to the right of the accused to a public hearing but also to ensure that other participants in criminal proceedings are safe and protected. In this context, providing anonymity to witnesses testifying would seem to be a meaningful infringement on the rights of the accused.

The use of anonymous witnesses, is a particularly controversial measure, however the international and domestic tribunals allow this practice, sometimes to justify the tribunals' impotence concerning physical protection of witnesses under threat (Affolder, 1998) and sometimes as a minimum guarantee for witness protection in order to ensure to the maximum the rights of the accused and a public trial.

The ICTY was established as a guarantee to deliver impartial judgements not only related to the accused but also to witnesses. In many cases, Judges acknowledged that they were cognizant that the rights of the accused are not absolute and a limitation would come as a necessity to protect the witnesses. The Prosecutor $v$. Tadic ${ }^{24}$ case remains the first case of ICTY where the Judges interpreted in details the protective measures for

${ }^{23}$ Ibid., para 42.

${ }^{24}$ The Prosecutor v. Tadic, "Decision on Motion by Prosecution for Protective Measures for Witness R", Case IT-94-1-T, 31 July 1996, p.4. See also The Prosecutor v. Tadic, "Decision on Motion by Prosecution for Protective Measures for Victims and Witnesses", 10 August 1995, para. 27; The Prosecutor v. Slobodan Milosevic, Decision on Prosecution motion for provisional protective measures pursuant to Rule 69, 19 February 2002, para. 23. 
witnesses. It established the principles and the basis of the ICTY jurisprudence on application for protective measures. The interpretation of the application and granting of protective measures has widely been used by the jurisprudence of international tribunals such as the International Criminal Court (ICC). Indeed the principle of proportionality was explained with the argumentation that "the obligation of the international tribunal to protect witnesses must not exceed the level of protection that they do indeed seek" ${ }^{25}$.

Anonymity as a means of protection of witness identity was indeed seen as a matter falling under the discretion of a trial judge, but in exceptional circumstances ${ }^{26}$ where there are for example derogation to some recognized fundamental rights. At national level, such circumstances may include cases of national emergency. By the provision of anonymity, the judges prevent the accused of any possibility to identify the witness. However, such anonymity should serve the interest of justice such as protecting against a genuine fear for the safety or the security of a witness or his or her family including in a context where no protection programme is available, permitting to hear a testimony that must be important for the prosecution case, and also understanding that prima facie the witness is trustworthy.

However, the granting of such anonymity as a protective measure was still considered by many as an infringement on defence rights. As stated by Monroe Leigh (1997:80) "every trial lawyer knows that effective crossexamination depends in major part on careful advance preparation. And this in turn depends on knowing the identity of accusing witnesses".

In relation to the power to provide appropriate protection for victims and witnesses in the ICTY Statute and Rules, it was held by the Trial Chamber that:

"...in the fulfilling of its affirmative obligation to provide such protection, the Tribunal has to interpret the provisions within the context of its own unique legal framework in determining where the balance lies between the accused's right to a fair and public trial, the right of the public to access of information and the protection of victims and witnesses. How the balance is struck will depend on the facts of each case."

The determining factors of this judgement were that at that moment, ICTY as an ad hoc International Tribunal was operating in the midst of a continuing conflict and was without a police force or witness protection programme to provide protection to victims and witnesses. However, the Judges stated that the consideration for the protection of victims and

${ }^{25}$ In Tadic, Decision of 10 August 1995.

${ }^{26}$ Lord Justice Evans, 22 July 1994, (English Court of Appeal, R. v. Taylor), line 17 of the transcript of the decision; cited in Tadic, 10 August 1995, para 60. 
witnesses are "unique". As opposed to human rights documents, neither Article 14 of the ICCPR nor Article 6 of the ECHR, which concerns the right to a fair trial, lists the protection of victims and witnesses as one of its primary considerations ${ }^{27}$.

Thus, the Judges argued that the interpretation given by other judicial bodies to Article 14 of the ICCPR and Article 6 of the ECHR is only of limited relevance in applying the provisions of witness protection, which do not contain the same considerations. Therefore, the Judges interpreted the provisions on witness protection and determined where the balance lied between the accused's right to a fair and public trial and the protection of victims and witnesses, within the context of its own unique legal framework.

Although protective measures mostly in-court were granted, and as already explained above, the limitation to the right of the accused to examine the witnesses without knowing their identities was considered by the judges as exceptional in particular circumstances. ICTY case-law established that this limitation does not mean violation when it is justified by the necessary protection of a witness or a victim but also for the necessity of justice. Indeed one may question whether the mandate of the Tribunal to establish justice is compromised when a witness refuses to testify for the case for fear or intimidation. The response is not convincing taking into account the frequent use of the subpoenas of witnesses who refused to testify. It seems prima facie that ICC has a more comprehensive approach in this respect since it lacks subpoenas and enacted the voluntary appearance of the witnesses.

It is worth highlighting that ICTY has revisited such jurisprudence particularly as in Blaskic case, it did ensure a balance between the right of the witness to be protected with the accused right to a fair trial, by notably distinguishing between periods before and after the commencement of a trial. The judges ruled that while protection could be granted to witnesses including by protecting their identity from the accused at preliminary stage until the start of the trial, "the right of the accused to an equitable trial must take precedence and require that the veil of anonymity be lifted in his favour, even if the veil must continue to obstruct the view of the public and the media" 28 .

In light of the above, the participatory legacy of the ICTY witnesses "is not only addressed as a static assessment of the ICTY's work but rather as a dynamic discourse and transformation process - a sharing of

${ }^{27}$ Ibid., Tadic.

${ }^{28}$ The Prosecutor v. Blaskic, "Decision on the Application of the Prosecutor Dated 17 October 1996 Requesting Protective Measures for Victims and Witnesses”, 5 November 1996) Case No. IT-95-14-T, para 24. 
experience and knowledge"29. Approximately 5,000 witnesses have made 8,000 appearances in trials before the ICTY since its inception. This unprecedented number includes a wide cross-section of victims, "crime base witnesses", "linkage witnesses", and expert witnesses.

One of the most interesting aspects of the ICTY is the important consideration that has been given to anonymity of witnesses and the "counterbalance" with the rights of the accused. Indeed, most international criminal courts have been unanimous in considering counterbalancing as an essential element to allow anonymity as a protective measure for the witnesses who were endangered to testify because of their testimony. The ICC and ICTY judges mostly determined that in-court and out-of-court protection was essential to bring victims to the court, especially in countries with complex conflicts and lack of security for victims and witnesses. For witnesses to be in position to give the "best evidence possible" in an ideal environment, they should feel reassured that their physical, emotional and psychological well-being is protected (Jackson and Brunger, 2015:602). Furthermore, ICTY judges justified anonymity of witnesses acknowledging the incapability of the Tribunal to guarantee the safety of the witnesses due to a lack of a fully-funded and operational witness protection programme.

\section{Contempt Of Court Cases: The Judicial handling of breaches of protective measures}

The security of witnesses in international tribunals seems to be one of the key challenges faced by international criminal justice mechanisms. The reasons behind this security-threat are related to highly political links that political and military leaders who stand trial still maintained back home in areas where many of the witnesses live. Indeed with the support of their governments, some international backing as well as community support back home, they seek to threaten witnesses and discourage them from testifying (Echoes of Testimony, 2016:60).

Many reports of the Council of Europe and the persistent declarations of ICTY Prosecutors expressed concerns about the pressure put upon witnesses, in particular their intimidation. ICTY Prosecutors have urged the States in which witnesses reside to continue assisting and cooperating with the Tribunal, emphasizing that it was "important to create a climate that is conducive for witnesses to testify and provide the necessary guarantees to witnesses who decide to speak before the Tribunal" 30 . Therefore, the ICTY is

${ }^{29}$ ICTY Legacy Dialogues, 22-24 June 2017 Sarajevo, Bosnia and Herzegovina - A conference reflecting on the legacy of the ICTY and how others can build upon its achievements.

${ }^{30}$ See for more the address of Serge Brammertz, the ICTY Prosecutor to the United Nations Security Council on 12 December 2008. 
notorious for many contempt cases in respect to allegations of disclosure of confidential information related to protected witnesses, or for cases of intimidation, threats or pressure, ${ }^{31}$ manipulation or bribing of witnesses ${ }^{32}$ because of their testimony.

The indictment of contempt related to witness intimidation gives a special value to the witness testimony considering that it can define the outcome of the trial. ${ }^{33}$ Thus, it means that a witness is an indispensable participant in establishing the truth. There is an indictment of contempt of Tribunal when there are reasons to believe that accused persons or individuals related to them had knowingly and willfully interfered with the administration of justice. This interference may include intimidation or other instances of tampering with witnesses, refusing to answer questions in court $^{34}$ or to comply with an order to attend a hearing or produce documents, disclosing confidential court documents and breaching protective measures.

The ICTY's jurisdiction does not expressly outline the contempt in the Statute. However, its exercise of the judicial function ensures its jurisdiction over such cases. Cases of contempt and intimidation fall under Rule 77 of the Rules of Procedure and Evidence which provides:

(A) The Tribunal in the exercise of its inherent power may hold in contempt those who knowingly and willfully interfere with its administration of justice, including any person who:

(ii) discloses information relating to those proceedings in knowing violation of an order of a Chamber;

(iv) threatens, intimidates, causes any injury or offers a bribe to, or otherwise interferes with, a witness who is giving, has given, or is about to give evidence in proceedings before a Chamber, or a potential witness.

Of the most serious precedents related to the indictment of contempt concerning the disclosure of confidential information to the public involving witnesses was the case against Vijoslav Šešelj who was convicted in three contempt cases under Rule 77(A)(ii) for knowingly disclosing confidential information in his book regarding the identities of protected witnesses in violation of the Trial Chamber's orders. ${ }^{35}$ The Trial Chamber sentenced

${ }^{31}$ The Prosecutor v. Astrit Haraqija And Bajrush Morina, "Judgement on Allegations of Contempt”, IT-04-84-R77.4-A, 17 December 2008.

${ }^{32}$ The Prosecutor v. Dusco Tadic, IT-94-1-A-R77, "Judgement on Allegations of Contempt Against Prior Counsel, Milan Vujin”, 31 January 2000.

${ }^{33}$ The Prosecutor v. Karadžić, Case No. IT-95-5/18-T, In The Contempt Case Of Berko Zečević, "Order in Lieu of Indictment", IT-95-5/18-R77.1, 4 February 2011.

${ }^{34}$ The Prosecutor v. Slobodan Milosevic Contempt Proceedings Against Kosta Bulatovic, "Decision On Contempt Of The Tribunal", Case No. IT-02-54-R77.4, 13 May 2005.

${ }^{35}$ The Prosecutor v. Vojislav Seselj. Case No. IT-03-67-R77.2, Judgement on Allegations of Contempt, 24 July 2009 (confidential; public version filed on the same day), paras. 31, 35, 41, 49 (confidential version); paras 21-23, 30 (public redacted version). 
Šešelj to fifteen months imprisonment and ordered him to secure the withdrawal of the book from his internet website and to file a report with the Registrar on the actions taken. Further, the Appeals Chamber stated that when Šešelj published his book, he was aware of the Trial Chamber's order that explicitly prohibited the publication of identifying details related to the protected witnesses and supported the Trial Chamber decision that "reasonably concluded that Ššelj possessed the mens rea to disclose information in violation of Trial Chamber's orders" ${ }^{\prime 36}$. The Appeals Chamber also noted that it was the established practice of the Tribunal to publish redacted public versions of documents that "contain information which, if disclosed, might cause prejudice, concerns about safety, or serious embarrassment to a party or a witness" ${ }^{\prime 3}$. The Chambers' decisions demonstrated that such disclosure of confidential witness information had a potential impact on witnesses' confidence in the Tribunal, and for this reason the Chambers recognized the need to discourage future violations of protective measure orders ${ }^{38}$.

Another contempt case relating to disclosure of confidential information was the one against the journalist and former spokeswoman of the Tribunal, Ms Florence Hartmann. The Chamber found that Hartmann knowingly and willfully interfered with the administration of justice by disclosing information including witness protective measures in violation of Appeals Chamber's orders through means of authoring for publication a book entitled Paix et Châtiment on 10 September 2007, and by authoring for publication an article entitled Vital Genocide Documents Concealed published by the Bosnian Institute on 21 January 2008. Even though no witnesses' names were disclosed and no witness harmed, the Judges argued that "the effectiveness of protective measures, orders and decisions is absolutely vital to the success of the work of the Tribunal" 39 .

\footnotetext{
${ }^{36}$ Seselj, Appeal Chamber Judgment (public redacted version) 10 May 2010, paras. 26, 29.

${ }^{37}$ Sesejl Appeal Chamber Judgment, para 32; Prosecutor v. Milomir Staki, Case No. IT97-24-A, "Decision on the Defence Motion for Extension of Time", 26 April 2004, para. 6. See also, The Prosecutor v. Ante Gotovina et al., Case No. IT-06-90-T, "Order Issuing a Public Redacted Version of the Confidential 'Decision on Motion for Provisional Release of Ivan Cermak' of 14 December 2009”, 14 January 2010; The Prosecutor v. Ladranko Prlic et al. Case No. IT-04-74-AR65.19, "Order Issuing a Public Redacted Version of the 'Decision on Prosecution's Appeal of the Trial Chamber's Decision to Provisionally Release Accused Praljak' Issued 17 December 2009”, 11 February 2010.

38 Sesejl Trial Judgement. para. 56 (confidential version); para. 37 (public redacted version). Appeal Chamber Judgment, para. 41.

${ }^{39}$ In the case against Hartmann, "Judgement on Allegations of Contempt", IT-02-54-R77.5, 14 September 2009, para. 80. See also The Prosecutor v. Ivica Marijačić and Markica Rebić, Case No. IT-95-14-R77.2, "Trial Judgement", 10 March 2006, para. 50
} 
Furthermore, Domagoj Margetić, a freelance journalist published the complete confidential witness list from the case Prosecutor v. Tihomir Blaškić on his website. He acknowledged that the witness identities he disclosed were protected; he revealed the identities of protected (international) witnesses who testified in non-public proceedings, the dates of the testimonies, the pseudonyms despite the fact that the witness testified in closed session ${ }^{40}$.

In Marijacić and Rebić, the Trial Chamber found that both Ivica Marijačić and Markica Rebić deliberately disclosed the identity of the protected witness, copies of the statement the witness gave to the OTP, and the transcript of the testimony the witness gave before the Trial Chamber in the closed session of the court during the course of the Blaškic trial. ${ }^{41}$ In the same case, the Appeals Chamber confirmed the judgment finding Josip Jovic guilty of contempt of the Tribunal for divulging the identity and excerpts from the testimony of Stjepan Mesic (former President of Croatia), who testified as a protected witness in the case concerning Blaškić.

Interference with witnesses by the defence counsels is not unknown. Milan Vujin, the counsel of Duško Tadić was convicted of contempt of the Tribunal. He allegedly instructed witnesses preparing to make statements to his co-counsel to lie; nodded his head to indicate to witnesses during their interviews when to say yes and when to say no; interfered with witnesses in a manner which dissuaded them from telling the truth; knowingly instructed a witness to make false statements to the Tribunal; and paid a person giving a statement money when pleased with the information provided but not paying him when he did not answer as instructed. ${ }^{42}$

It is obvious that the ICTY case-law indicates that disclosure of confidential information in particular of protected witnesses' identity to the Defence team, in accordance with the rights of the Defence, impaired "their anonymity and thereby their protection. Once protected witnesses have been identified, the Defence team can easily put pressure on them and their families ",43.

For instance, Bajrush Morina was found guilty of contempt of the Tribunal for knowingly and willfully interfering with the administration of justice by pressuring on a protected witness to persuade him not to testify for

${ }^{40}$ The Prosecutor v. Domagoj Margetic, Case No. IT-95-14-77.6, Judgement on Allegations of Contempt, 7 February 2007.

41 The Prosecutor v. Ivica Marijačić and Markica Rebić, Case No. IT-95-14-R77.2, "Judgement", 10 March 2006.

42 The Prosecutor v. Dusko Tadic, Case No. IT-94-1-A-R77, "Judgment On Allegations Of Contempt Against Prior Counsel, Milan Vujin", 31 January 2000, para.2.

${ }^{43}$ Jean-Charles Gardetto, Memorandum on "The protection of witnesses as a cornerstone for justice and reconciliation in the Balkans", Committee on Legal Affairs and Human Rights of the Council of Europe, AS/Jur (2009) 38, 3 September 2009, para. 20. 
the Prosecution in the trial of Ramush Haradinaj, Idriz Balaj and Lahi Brahimaj. The unprecedented atmosphere of widespread and serious witness intimidation that surrounded the trial ${ }^{44}$ and the unstable security situation created a lot of difficulties in securing the testimony of a large number of witnesses. The Trial Chamber gained a strong impression that the trial was being held in an atmosphere where witnesses felt unsafe. As a consequence, this situation was particularly unfavourable to witnesses to guarantee their anonymity also because of specific factors related to a region composed of small communities, the cultural background of witnesses (the notion of honour, moral code, blood kinship, the pledge of alliance or besa) tight family ${ }^{45}$. For the Tribunal to function effectively, Trial Chambers "must counter witness intimidation by taking all measures that are reasonably open to them, both at the request of the parties and proprio motu 46 ".

The trials of Haradinaj et al. and Limaj et $a .^{47}$ were impeded by serious pressure on witnesses; allegedly several of them refused to testify, some withdrew their statements against the accused persons ${ }^{48}$ and some were killed. As the ICTY Prosecutor Carla Del Ponte wrote in her memoir:

"Proving witness tampering is extremely difficult, especially in a lawless region.... During the Limaj trial, more witnesses told prosecution attorneys that they had received threats. Some received notes. Some received phone calls. Some heard automatic weapons fire into the air outside their houses. Some reported that the local police officers has searched their houses and followed their children. One man noticed the red dot of laser target spotter painting his wife's face. Attorneys from the Office of the Prosecutor travelled repeatedly to Kosovo ... to convince witnesses to testify. After one of them gave evidence, gunmen fired several dozen rounds from an automatic weapon into his car, miraculously missing him and his fourteen-year-old son. Another had his car blown up and lost his leg before the tribunal moved him to a third country." (Del Ponte and Sudetic, 2009:288-289)

\footnotetext{
${ }^{44}$ The Prosecutor v. Ramush Haradinaj, Idriz Balaj, and Lahi Brahimaj, Case No. IT-0484-T, Appeal Judgment, 10 July 2010, para. 35.

${ }^{45}$ The Prosecutor v. Ramush Haradinaj, Idriz Balaj, and Lahi Brahimaj, Case No. IT-0484-T, Trial Judgement, 3 April 2008. para. 6.

${ }^{46}$ Haradinaj Appeal Judgement, para. 35

${ }^{47}$ The Prosecutor v. Fatmir Limaj, Haradin Bala, and Isak Musliu, Case No. IT-03-66.

48 The Prosecutor v. Beqa Beqaj, Case No. IT-03-66-T-R77, Judgement on Contempt Allegation, 27 May 2005.
} 


\section{Conclusion}

Witness protection problems in the ICTY occurred because the former Yugoslavia region was suffering widespread and systematic witness intimidation that was having a significant impact upon the criminal proceedings both locally and before the Tribunal (Del Ponte and Sudetic, 2009:297) on the one hand, and the lack of action of the United Nations Interim Administration Mission In Kosovo (UNMIK) ${ }^{49}$ on the other hand; because the UNMIK was not taking any steps to seriously address the exceptionally dangerous situation in which the witnesses testifying before the Tribunal were (Del Ponte and Sudetic, 2009:297-299).

Despite the fact that many prosecution witnesses were reluctant to testify considering the serious problem of direct and veiled intimidation and threats towards them, the protection of witnesses who had the courage to come forward to tell the truth has however been of critical importance ${ }^{50}$ (Del Ponte and Sudetic, 2009:302).

However, the lack of consideration to grant witnesses procedural and non-procedural protective measures mostly due to financial problems, and forcing them to testify in a public hearing with subpoenas when a real risk of intimidation existed, reinforced the impunity of war criminals and facilitated the acquittal of many of them. Evidently, the non-adequate witness protection in ICTY affected the establishment of the truth and endangered the administration or interest of justice.

Specific factors such as witness cultural background, small community and tight family were other challenges that influenced the effectiveness of protective measures. Moreover, duration of protective measures (short-term) in an environment which was struggling with post-war economic, social and political confusion caused witness mistrust. Therefore, determining how long the victim and witness protection function would need to remain operational was a difficult assessment to make for a Tribunal which ceases to exist despite the fact that MICT is going to handle the continuance of witness protection services. This might require MICT to provide support until at least the last witness is deceased, or, where applicable, until the cessation of protective measures covering a witness's immediate family members, and in relation to the relocated witnesses, until the last member of the immediate family is deceased.

Misperceptions of the role of the Tribunal, its support unit and lack of information related to the cases have resulted in deep disappointment for many ICTY witnesses. Therefore, one of the effective solutions for the

\footnotetext{
${ }^{49}$ UNMIK was established pursuant to Security Council Resolution 1244, which was passed on 10 June 1999.

${ }^{50}$ See also Prosecutor v Ramush Haradinaj, Idriz Balaj, and Lahi Brahimaj, Case No. IT04-84-T, Transcript of 5 March 2007, pp. 359-360.
} 
ongoing trials such as the Kosovo Special Chambers and future cases in other criminal proceedings in general is that witnesses need to receive timely and accurate information on the support services of special units, the court's mandate and role, including rules and procedures on compensation for the victims, to adequately manage the witnesses' expectations and prevent disillusionment.

\section{References:}

1. Statute of the International Tribunal for the Former Yugoslavia (ICTY)

2. Rules of Procedure and Evidence ICTY

3. UN Security Council Resolution 1966 (2010) for the establishment of MICT

4. UN Security Council Resolution 1244 for the establishment of the UNMIK

5. Affolder, N. A., (1998) "Tadic, the Anonymous Witness an the Sources of International

6. Procedural Law”, 19 Michigan Journal of International Law 445

7. De Brouwer, A., (2015), "The Problem of Witness Interference before International Criminal Tribunals", in International Criminal Law Review

8. Morris, V., and Scharf. M., (1995), An Insider's Guide to the International Criminal Tribunal for the Former Yugoslavia. A Documentary History and Analysis, 2 volumes, Irvington-on-Hudson, NY: Transnational Publishers, Inc.

9. Del Ponte, C., and Sudetic, Ch. (2009) Madame Prosecutor: Confrontations with Humanity's Worst Criminals and the Culture of Impunity, A Memoir, The Other Press

10. Ackerman, J.E., and O'Sullivan, E., (2000) Practice and Procedure of the International Criminal Tribunal for the Former Yugoslavia with selected materials from the International Criminal Tribunal for Rwanda, Kuwer Law International

11. Bonnet, L. (2005) La Protection Des Temoins Par Le Tribunal Penal International Pour L'ex-Yougoslavie, Droits fondamentaux, no. 5.

12. Jackson J.D and Brunger, Y.M., (2015), "Witness Preparation in ICC - An Opportunity for Principled Pragmatism", Journal of International Criminal Justice 13, 606

13. McLaughlin, C.T., (2007), Victim and Witness Measures of the International Criminal Court: A Comparative Analysis" The Law and Practice of International Courts and Tribunals 6 
14. McLaughlin, C.T., (1997), The International Criminal Tribunal for the Former Yugoslavia: Recent Developments in Witness Protection, 10 Leiden Journal of International Law 179, 181

15. Monroe Leigh, Witness Anonymity is Inconsistent with Due Process, 91 AM. J. INT'L L. 80 (1997)

16. Resolution 827 "Establishing an International Tribunal for the Prosecution of Persons Responsible for Serious Violations of International Humanitarian Law Committed in the Territory of the former Yugoslavia", UN. Doc. S/RES/827 25 May 1993

17. Gardetto, J., (2009), Memorandum on "The protection of witnesses as a cornerstone for justice and reconciliation in the Balkans", Committee on Legal Affairs and Human Rights of the Council of Europe, AS/Jur (2009) 38

18. "Echoes of Testimonies - A Pilot Study into the long-term impact of bearing witness before the ICTY" (2016)

19. ICTY Legacy Dialogues, 22-24 June 2017 Sarajevo, Bosnia and Herzegovina - A conference reflecting on the legacy of the ICTY and how others can build upon its achievements.

20. Serge Brammertz, the ICTY Prosecutor to the United Nations Security Council on 12 December 2008

\section{Table of Cases}

21. Le Procureur v. Dusco Tadic, Décision relative à l'exception préjudicielle soulevée par le Procureur aux fins d'obtenir les mesures de protection pour les victimes et les témoins, affaire $\mathrm{n}^{\circ} \mathrm{IT}-94-1-\mathrm{T}$, Ch. 1ère instance, 10 août 1995

22. The Prosecutor v. Dusco Tadic, Decision on Motion by Prosecution for Protective Measures for Witness R., Case IT-94-1-T, 31 July 1996

23. The Prosecutor v. Dusco Tadic, Judgement on Allegations of Contempt Against Prior Counsel, Milan Vujin, Case IT-94-1-A-R77, 31 January 2000

24. The Prosecutor v. Zlatko Aleksovski, Décision Portant Condamnation Pour Outrage Au Tribunal, IT-95-14/1-T, 11 December 1998; cited in: ICTY Press Release, 'Mr. Nobilo Found to be in Contempt of the Tribunal', 15 December 1998.

25. The Prosecutor v. Ante Gotovina et al., Case No. IT-06-90-T, Order Issuing a Public Redacted Version of the Confidential "Decision on Motion for Provisional Release of Ivan Cermak" of 14 December 2009, 14 January 2010

26. The Prosecutor v. Ladranko Prlic et al. Case No. IT-04-74AR65.19, Order Issuing a Public Redacted Version of the "Decision on Prosecution's Appeal of the Trial Chamber's Decision 
to Provisionally Release Accused Praljak" Issued 17 December 2009, 11 February 2010

27. The Prosecutor v. Milomir Staki, Case No. IT-97-24-A, Decision on the Defence Motion for Extension of Time, 26 April 2004

28. The Prosecutor v Ramush Haradinaj, Idriz Balaj, and Lahi Brahimaj, Case No. IT-04-84-T, Transcript of 5 March 2007

29. The Prosecutor v. Blaskic, "Decision on the Application of the Prosecutor Dated 17 October 1996 Requesting Protective Measures for Victims and Witnesses", Case No. IT-95-14-T, 5 November 1996

30. The Prosecutor v. Astrit Haraqija And Bajrush Morina, Judgement on Allegations of Contempt, IT-04-84-R77.4-A, 17 December 2008

31. The Prosecutor v. Beqa Beqaj, Case No. IT-03-66-T-R77, Judgement on Contempt Allegation, 27 May 2005

32. The Prosecutor v. Fatmir Limaj, Haradin Bala, and Isak Musliu, Case No. IT-03-66

33. The Prosecutor v. Kolundzija, Order for Protective Measures, IT-958-PT, 19 October 1999

34. The Prosecutor v. Naser Orić, Case No. MICT-14-79, Decision on an Application for Leave to Appeal the Single Judge's Decision of 10 December 2015, 17 February 2016

35. The Prosecutor v. Nikolic, "Confidential Decision on Second Motion by Prosecution for Protective Measures", Case No. IT-94-2-PT, 29 November 2000

36. The Prosecutor v. Radovan Karadžić, Case No. IT-95-5/18-T, In The Contempt Case Of Berko Zečević, Order in Lieu of Indictment, IT95-5/18-R77.1, 4 February 2011

37. The Prosecutor v. Radovan Karadžić, Case No. MICT-13-55-A, Decision on a Motion to Compel Inspection of Pseudonyms of Witnesses Subject to Ex Parte Rule 86 Proceedings, 22 May 2017

38. The Prosecutor v. Ramush Haradinaj, Idriz Balaj, and Lahi Brahimaj, Case No. IT-04-84-T, Trial Judgement, 3 April 2008

39. The Prosecutor v. Ramush Haradinaj, Idriz Balaj, and Lahi Brahimaj, Case No. IT-04-84-T, Appeal Judgment, 10 July 2010

40. The Prosecutor v. Tadic, "Decision on Motion by Prosecution for Protective Measures for Victims and Witnesses", 10 August 1995

41. The Prosecutor V. Slobodan Milosevic Contempt Proceedings Against Kosta Bulatovic, Decision On Contempt Of The Tribunal, Case No. IT-02-54-R77.4, 13 May 2005

42. The Prosecutor v. Slobodan Milosevic, Decision on Prosecution motion for provisional protective measures pursuant to Rule 69, 19 February 2002 
43. The Prosecutor v. Vojislav Seselj. Case No. IT-03-67-R77.2, Appeal Chamber Judgment (public redacted version) 10 May 2010

44. The Prosecutor v. Vojislav Seselj. Case No. IT-03-67-R77.2, Judgement on Allegations of Contempt, 24 July 2009

45. R. v. Taylor, 22 July 1994 